\title{
Facilitation as a teaching strategy: The experiences of nursing students
}

\author{
E Lekalakala-Mokgele, PhD \\ School of Nursing, University of the Free State \\ P du Randt, PhD \\ School of Nursing, University of the Free State
}

Keywords:

Facilitation, problem-based learning, selfdirected learning

\section{Correspondence address:}

Dr E Lekalala-Mokgele

School of Nursing

University of the Free State

PO Box 339

Bloemfontein

9300

Tel: (051) 401-2407

Fax: (051) 401-9463

E-mail: gnvkem.MD@mail.uovs.ac.za

\section{Abstract: Curationis 28(4): 5-11}

This study was undertaken to assess the needs/problems of students of nursing regarding facilitation as a teaching/learning method. Facilitation as a teaching and learning strategy was uncommon and innovative in nature and presented a challenge to the students as it was a new way of learning. Focus group interviews were conducted. The sample study consisted of eight (8) groups of learners from four universities engaged in this curriculum. To answer the research question a qualitative, exploratory, descriptive design was used and the students were selected purposively. Data analysis using transcribed focus interviews, was based on the combined approaches of Tesch (1990) in Cresswell (1994:153-155) and the basic steps of Giorgi (1970) as quoted by Omery (1983:49-63). The themes identified were about the experiences of the facilitation process and problems with the facilitators. All the students experienced the facilitation of learning negatively in the beginning but became more positive later when they adapted to this method of learning.

\section{Opsomming}

Die studie is onderneem om die behoeftes/probleme van studente oor fasilitering as ' $n$ onderrig/leer metode te bepaal. Fasilitering as 'n onderrig/leerproses was ongewoon en innoverend van aard vir die studente en het uitdagings aan hulle gestel. Fokusgroep onderhoude is gehou en die steekproef het bestaan uit agt (8) groepe leerders uit vier universiteite wat problem-gebaseerde leer geÿmplementeer het. 'n Kwalitatiewe, verkennende en beskrywende ontwerp is gebruik en studente is doelgerig geselekteer. Die data is geanaliseer deur gebruik te maak van die gekombineerde benadering van Tesch (1990) in Creswell (1994:153-155) en die basiese stappe van Giorgi (1970) soos aangehaal deur Omery (1983:49-63). Die temas wat geïdentifiseer is het verband gehou met die ervarings van studente met betrekking tot fasilitering sowel as probleme met die fasiliteerders. Al die studente het fasilitering aanvanklik negatief ervaar maar het meer positief geraak namate hulle die proses van fasilitering aangepas het.

\section{Introduction}

For decades the schools and universities in South Africa implemented a learning system which was lecture-based and content oriented. In the nineties education was put under pressure to change from lecture-based and content oriented approaches to student-based learning. This transformation has also put nursing education in the spotlight to change (Republic of South Africa, 1995:5). For the education of nurses at university level it would mean the following: Students would take a more active part in learning while lecturers changes their roles from that of autocratic dictators to that of facilitators of leaming, leading students on their own paths of creative thinking. Students then would formulate and solve problems themselves and while being lead by a facilitator to develop their own paths of thinking.

The new orientation of learning came 
about in 1997 when the higher education policy directed tertiary institutions to broaden participation in the education to satisfy the developmental needs of the whole society (Republic of South Africa, 1997:1). In accordance with this directive some of the nursing departments in South Africa introduced community-based education (CBE), and problem-based learning (PBL), a student-centred approach which is different from the previous lecture based and content focused approach. The students were not used to self-directed learning. The challenge flowing from this change in education strategy is to produce students who, at the end of a of a baccalaureate degree, are self-directed learners. This challenge faces all educators in higher education as educators should aim more broadly to develop the self-learning skills and personal growth of students (Uys \& Cassimjee, 1997:132-138).

\section{Problem statement}

The majority of students entering university come from a traditional learning background which is lecturebased and content oriented. According to Conrick (1994:237) these students have been indoctrinated over twelve years in the educational behaviourist theory which limited their development of selfdirected learning and problem solving. Until recently the same approach was used in nursing education. In contrast with this approach problem-based learning (PBL) demands active participation from the students. The students who register for the undergraduate nursing course come from school backgrounds where self-directed learning until recently has not been encouraged (Becker, 1999:4). Students therefore have to negotiate a range of adaptations as they make a transition from traditional learning behaviours to the selfdirected, student-centred approach (Davies, 2000:15). It is during this transition that the students do not cope and experience problems with facilitation. Boulton-Lewis, Wilss and Mutch (1996:84-106) found that students who continue with tertiary study bring with them considerable informal and formal knowledge of the learning process derived from earlier formal study. These students still need to adapt to the facilitation process.

It was clear from these statements that the general education in any university must respond to the needs of the students who enroll at these institutions (Giczkowski, 1995:13). Since students are unfamiliar with learning by using facilitation, their needs regarding the method are not known. It is therefore important to make an assessment of their needs in order to identify problems they may encounter.

\section{Aim of the study}

The aim of this study was to determine the experiences of students with regard to facilitation in the problem-based learning (PBL) and community-based education (CBE) undergraduate programme of the Schools of Nursing of four (4) universities in South Africa implementing PBL in their curriculum.

\section{Objectives}

The objectives were to:

-
students in PBL and CBE
determine the needs of students
in PBL and CBE
make recommendations
regarding the preparation and
future support of students in
PBL and CBE

\section{Research design}

To answer the research question a qualitative, explorative, descriptive and contextual approach was used.

\section{Population and sampling}

The population of this study was purposively selected and included the learners in the schools and departments of nursing of four (4) South African universities using facilitation as a teaching-learning method. Two main groups consisting of first and fourth years students were selected in each university. The first years were in different group than fourth years. The researcher purposefully decided to include the first and the fourth year students for the purpose of obtaining the experience of those who have never being exposed to facilitation and those who had a great amount of exposure. The reason was that the experiences were expected to be different and it was easy to obtain data from a homogeneous group.

In total focus group interviews were conducted with eight (8) groups of students from four (4) universities. One group of the total of eight (8) was used as a pilot study. Each group of students consisted of males and females from different cultural backgrounds. They also differed in their level of academic achievement ranging from low, average to high achievers. Each group consisted of learners in the same year of study.

\section{Data collection}

Data was obtained by conducting focus group interviews with students. This is a special kind of interview situation that is largely qualitative. The moderator conducted focus interviews. The purpose of the interviews for this study was to obtain in-depth information from a few cases. This is characteristic of qualitative research (Moloto, 1999:38). Data was collected until saturation was reached (Parse, Coyne, \& Smith, 1985:17). One primary open-ended question was asked and it was, : "How do you experience facilitation as a teachinglearning method?'. Field notes were taken by the researcher. These are broad, more analytical and more interpretive than a simple listing of occurrences (Polit \& Hungler, 1993:215-216). The field notes were taken to validate information given by participants.

\section{Data analysis}

Data was analyzed using the qualitative analysis technique of Tesch (1990) as explained in Creswell (1994:153-154), as well as the basic steps for qualitative analysis by Giorgi (1970) as quoted by Omery (1983:49-63). According to Tesch (1990) data analysis requires that the researcher be comfortable with developing categories. The transcribed audio-taped material from the focus group interview is reduced to categories and then themes which are interpreted according to Tesch (1990) called "decontexualisation" and "recontexualisation" is done. This analysis process consists of "taking apart" smaller pieces whereby the final goal will be the emergence of a larger consolidated picture (Tesch, 1990:97 in Creswell, 1994:154). Reading the transcripts repeatedly, identifying summaries, eliminating redundant information, transforming concrete information to usable scientific data then categorizing it according to repeated tendencies constituted the steps of data analysis according to Giorgi (1970). The researcher read through all interviews. As topics emerged, they were written in the margin. When this was completed, a list 
of all identified topics was made. Similar topics were clustered together, and this were arranged as major topics. Then the best fitting name that captured the substance was chosen for the clustered topic.

The clustered were abbreviated as codes The codes were written next to the appropriate segment of the text. This process led to the discovery of new topics that were not previously identified. In summary it can be stated that data was organized and refined; the most descriptive wording for the topics was found and then were turned into categories.

\section{Reliability and validity of data analysis}

In this research consistency, dependability, conformability, credibility and transferability (Leiniger 1991 in Brink 1996:124) were used to ensure reliability and validity. Four criteria for trustworthiness in terms of true-value, applicability, consistency and neutrality will be discussed.

\section{Credibility (truth-value)}

Truth-value determines whether the researcher has established confidence in the credibility of the findings of the research. In qualitative research credibility refers to internal validity (Brink, 1996:124). In this research crossexamination of data was carried out to confirm the credibility of the results. A literature review was conducted to control the data by comparing it with available literature and relevant research.

The researcher conducted crossexamination by arranging for a moderator to be present during focus interviews whilst the researcher took field notes. The researcher and the moderator compared their data directly after focus group interviews to validate that information was heard correctly.

\section{Transferability (applicability)}

Generalization cannot be made in qualitative research because every research situation is made up of a particular researcher in particular interaction with particular informants (Lincoln \& Guba, 1985:316). The study will therefore provide only the description necessary to enable someone interested in making a transfer to reach a conclusion that transferability may be contemplated as a possibility.
Dependability (consistency)

Consistency determines whether the findings would be consistent if the inquiry were replicated with the same participants in a similar context. Variability can be expected in qualitative research due to the fact that the instruments assessed are the researcher and informants, both of whom vary greatly within the research project. Seeing that qualitative research emphasizes the uniqueness of the human situation, it is variation rather than identical replication that is sought (Field \& Morse, 1985:11). Because variability can be expected in qualitative research, consistency is defined in terms of dependability. The research findings therefore depend on whether the learners have had more experience of the facilitation process because if they do then data will differ. To ensure consistency students in the same year of study were grouped together for example first years were interviewed together but separate from fourth years. The same was done with the fourth years.

\section{Confirmability (neutrality)}

Conformability guarantees that the findings, conclusions and recommendations are supported by the data and that there is internal agreement between the investigator's interpretation and the actual evidence (Brink, 1996:125). Neutrality refers to the degree to which findings are a function solely of the informants and conditions of the research. Freedom from bias in the research procedures and results is important, not the researcher's prior notions, motivations and perspectives. In qualitative research the value of findings increases when the distance between the researcher and informants is decreased (Lincoln \& Guba 1985:323). These writers shift the emphasis of neutrality from the researcher to the data. The neutrality of the data becomes the important factor and not the neutrality of the researcher. Lincoln and Guba (1985:323) further suggest that conformability is the criterion of neutrality which is achieved when truth-value and applicability of data is established. Neutrality in this research was maintained by the following:

- $\quad$ Being close to participants when conducting focus group discussions during data collection increased the value of the findings and fulfilled this criterion. The moderator was closer to respondents because she was the one interacting with them.

- $\quad$ The moderator had no knowledge of the participants. Participants were not subordinates to the moderator participants.

- $\quad$ The moderator was not involved in the research except by conducting focus group discussions and becoming a cocoder during data analysis.

- $\quad$ The moderator was an expert with regard to group dynamics as she was a psychiatric nurse specialist with qualitative research experience.

The moderator was an expert in conducting focus group interviews in an objective manner and that added to the maintenance of neutrality.

\section{Ethical issues}

Participants were fully informed about the research. Students were invited to participate freely and to mention their needs as well as problems without fear of victimization or intimidation. Confidentiality was maintained as raw data was only accessible to the researcher and the independent coder. Recorded data was destroyed when the research was completed. Participants were also informed that they had the right to withdraw from the research if they did not want to continue. The researcher must respect the autonomy of participants to decide about their involvement in any research study (Gelling, 1999:42). To ensure that this ethical issue was adhered to the protocol was subjected to the critique of the Ethical Committee of the Faculty concerned. Permission was sought and granted by all authorities where research was conducted.

\section{Definition of concepts} Facilitation

Facilitation is a learning process where students are led by a facilitator through their own paths of thinking to show how they come to a certain conclusion (White \& Ewan, 1991:107).

\section{Problem-based learning}

A definition of PBL is elusive because several variations have been developed 


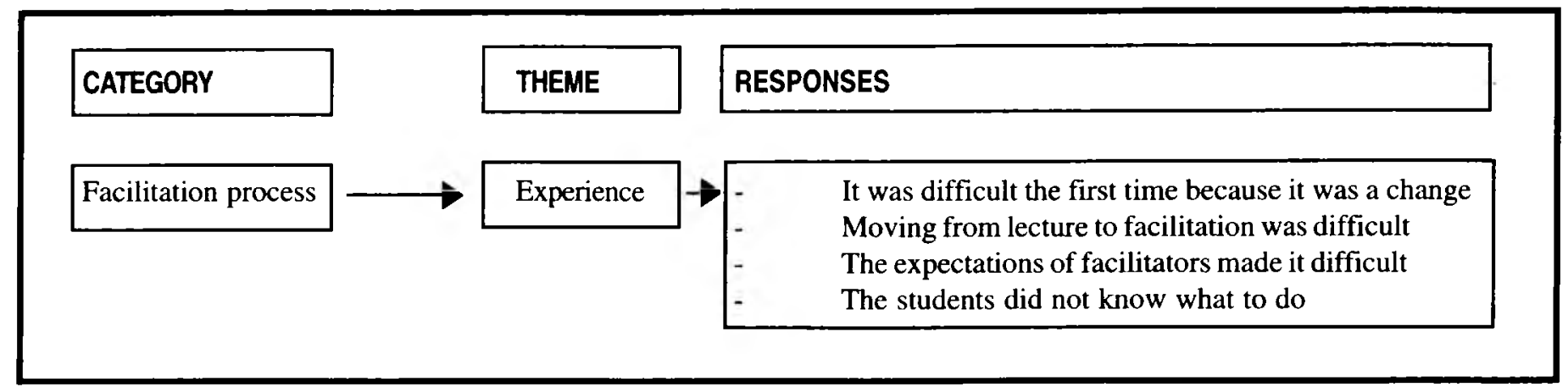

(Chen, Cowdroy, Kingsland \& Ostwald, 1994:7). Some researchers, such as Boud and Felleti (1991:21) define PBL as an integrative programme of study that engages students in problem-formulation and solving. For the purpose of this study PBL is an instructional method in which the students are self-directed in their learning using patients' problems to learn problem solving skills.

\section{Self-directed learning}

This is a student-centred approach where students are facilitated into an active role in learning (Moloto, 1999:24). Brookfield (1985), as quoted by Uys and Cassimjee (1997:132-138), states that self-directed learning does not mean that students' work completely on their own but that they interact with resource people.

\section{Results and discussions}

Three main themes regarding facilitation process were identified ; experience of the students in general, feelings/ emotions related to facilitation process and problems related to facilitators. Responses from students as indicated in figure 1 explains the reasons for them experiencing facilitation process negatively when they were initially introduced to this strategy of learning.

\section{Students' experience of}

\section{Figure 2 Emotions of students}

\section{facilitation method in general}

All the students stated that they found facilitation initially difficult due to various reasons as indicated in Figure 1.

The students mentioned that it was difficult for them to adapt to the process of facilitation because to them it involved change from the lecture method which they were accustomed to as indicated in figure 1. The following excerpts and accompanying literature illustrates the students' experiences

"The first time it was difficult for me because it is a change from what we are used to".

"It is not done like the way it is done at school. At school we are just basically lectured".

"You are so used to having someone standing in front of you and lecturing at school and all of a sudden all that changes. It becomes a challenge".

The school setting is different from the university. Students at school are used to relying on their teachers as the source of information. For the most part they do not challenge the teacher and the information imparted to them is taken as "gospel" meaning something which is safely believed (Conrick, 1994:238). Rees
(1991:43) affirms that there are basic principles for initiating change, namely that it takes time, it is a process, not a decision and requires a lot of experience and practice in the new way of doing things. The following quotation by Halpern (1994:10) confirms that change is difficult in higher education : "It has been said that changing a university is a lot like moving a cemetery - you don't get a lot of help from the residents".

Facilitator's expectations of student performance made their experience of the facilitation process more difficult as one said: "I must say for the first time it is really difficult and the difficulty is the expectation, they will just say you have to go and search. You don't know the information that they want". According to Rogers (1998:70-71) the facilitators' expectation is a single reflection of what they experienced in the past and therefore have come to expect for the future and the future being the students. Chalmers and Fuller (1996:15016) state that students come to class holding certain conceptions of learning and teaching. They have expectations about how they will go about learning and how the teacher will go about teaching.

The students verbalized that their knowledge about what was expected of

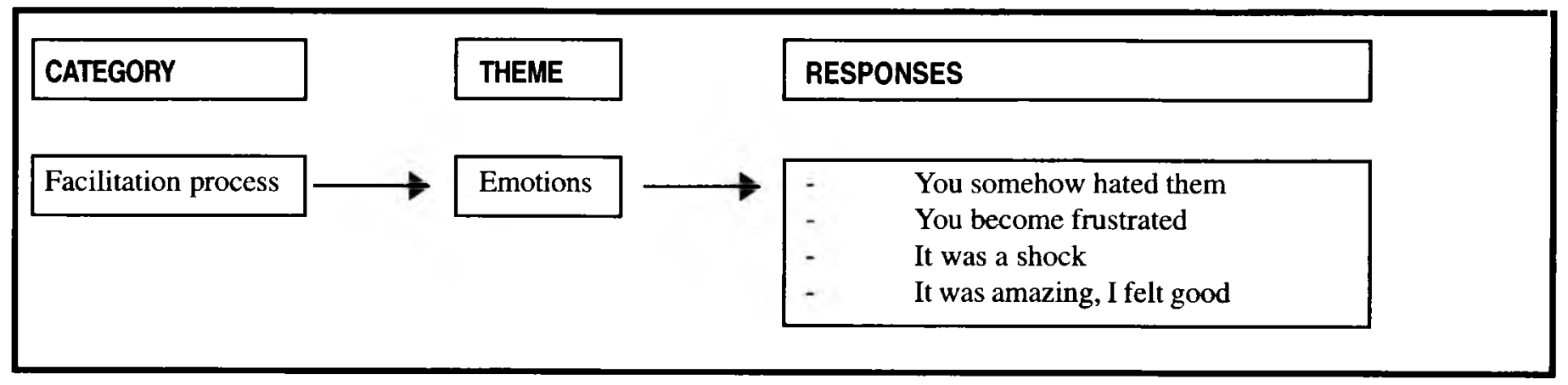




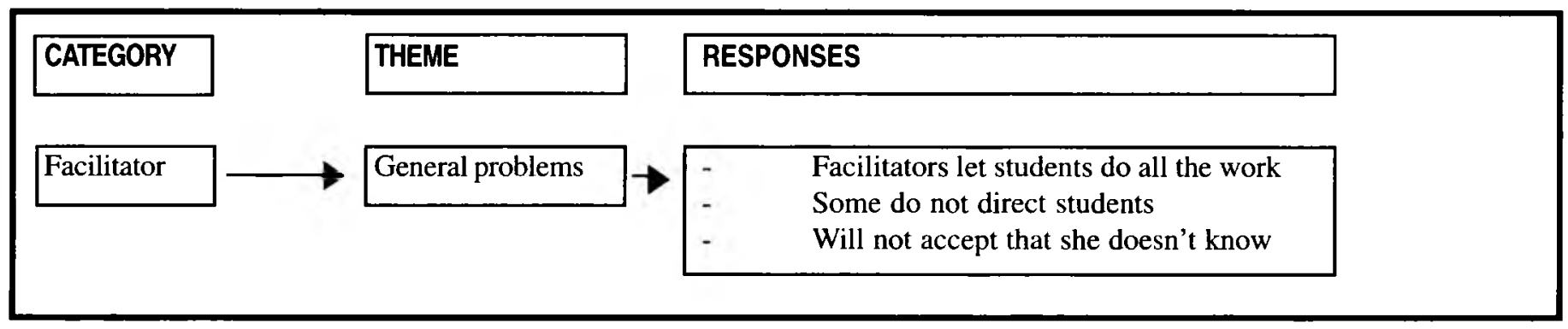

them when they were initially facilitated was limited. In the context of this study students found facilitation abstract and difficult to understand because they were not previously exposed to this teaching/learning method. Charlin, Mann, \& Hansen (1998:323-330) urge facilitators to help students to build and develop a rich network of knowledge.

\section{Emotional experienced by students}

The difficulty of facilitation process and the expectations of facilitators elicited certain emotions amongst the students. The students in this research expressed mostly negative emotions when they were first facilitated but positive emotions were also expressed as indicated in Figure 2.

Figure 2 denotes emotions as mentioned by the students during data collection. These emotions were both negative and positive for some students. The following excerpts illustrates the how students' expressed those emotions

"Looking at the person who introduced PBL you somehow hated them".

"The difficulty is you become scared and depressed".

"Initially it was more of a shock than anything"

Students opinions may have been that that they could not learn by being facilitated as they did not understand the facilitation process and this was the possible cause of negative emotions amongst them. Researchers have found that starting a degree may cause frustrations especially when student expectations about the university turn out to be entirely different from what they envisaged when the subject's content differs from what they expected (Peelo, 1994:37). Most students were shocked by the idea of being facilitated and not lectured. The shock may be related to the expectations about the course and the responsibility associated with it (Taylor, 1997:28).

One student experienced facilitation positively and said: "For me it was amazing, I had to be my own lecturer, it was just a wow!! I felt good that I have done something". This student demonstrated positive feelings in contrast to other students. Kirkpatrick (1985) in Holtzhausen (1999:54) states that change, with special reference to higher educational change, causes different emotions within different individuals as some will associate it with anxiety and fear whilst others view it with hope and as a solution.

\section{Problems that students experienced with facilitators}

The students spelt out some general problems with facilitators which they experienced as hindrances that contributed to making facilitation difficult as indicated in Figure 3.

During data collection it seems that students were dissatisfied about their facilitators because of lack of understanding of the facilitation process as indicated in figure 3.

The students views were that facilitators were not working and that they gave their work to them. One student said: "Another thing you see that the facilitators they are just resting, they are taking all the work to the students. You don't see if the facilitator has prepared anything they dig information from you". This is a classical case of misunderstanding of self-directed learning (Brookfield (1985) in Uys \& Cassimjee, 1997:132-138). As such the facilitator can be seen as inherently lazy because of the changed roles. Brookfield (1995:13) states that learners often complain that facilitators are abdicating their educational role by placing on the learners the responsibility for making judgments about the content and direction which they as students are not equipped to do.

Townsend (1994:107) emphasizes that students need to take control of their learning and become self-sufficient learners who are pro-active, challenge and question set deadlines. Furthermore they must find resources for themselves and facilitators must let go of their authority to enhance student growth and autonomy. Other students experienced that facilitators did not guide them because of the perception of their being self-directed learners. The following excerpt and accompanying discussions from the literature illustrate this experience of the students:

"I think it has to be explained thoroughly to some of the lecturers, because although the student works independently the lecturer has to participate by directing students. It seems other lecturers do not know that. When they come to facilitate all that they said was that, 'I understand that you are PBL students' and they gave us no direction".

This is also a problem related to the misconception of self-directed learning (SDL). In SDL the process of leaming and teaching is learner-centred (Lunyk-Child, Crooks, Ellis, Ofosu., O'Mara. \& Rideout, ,2001:117).

Rooth (1995:25) has observed that some facilitators incorrectly believe that because there is a great deal of freedom in facilitation, one should give minimal direction. Eaton (1999:85) states that in a learning environment a certain type of experience has to be gained but learners do not know specifically what is available to extend their learning, and require a great deal of guidance. It is therefore imperative that facilitators guide the students on how to extend their learning by giving them structure.

Students were frustrated with facilitators 
who would not accept that they lack knowledge in some areas. One student asserted: "When you say something that she doesn' $t$ know she will not accept it, she thinks it is wrong because she doesn't know". This behaviour shows lack of knowledge of the self and selfunderstanding. Mulholland (1994:42) found that in open discussions as in facilitation, gaps in knowledge become apparent and learners may ask questions to which the teacher does not know the answer. This is threatening to authoritarian teachers who are required to facilitate learning . Mulholland (1994:42) explains that it is not necessary to know everything or even pretend to have knowledge. Rooth (1995:21) mentions that it is important that facilitators become aware of their limits and be wiling to acknowledge that they do not know everything. They should have a strong sense of who they are, believe in themselves, know their potentials, abilities and limitations. Brockbank and McGill (1998:161) state that facilitators must recognize that they can make mistakes and admit that they do not know everything.

\section{Conclusions}

It is very evident from the discussion that the students experienced facilitation as a difficult teaching method because of the way in which facilitation differs from the lecture method. Katz (1995:54) states that in facilitation there is a change in the locus of control because the students are involved in their learning. Brown and Smith (1996:49) agree that with the traditional lecture method the content of the material is entirely within the control of the lecturers. It is indeed this lack of control that threatens the students as well as the facilitators and which makes them reluctant to want to accept that they lack knowledge in some areas. Students should be encouraged to seek information regarding strategies that institutions will use to educate them when they apply to study. Orientation sessions that simulate facilitation process should be organized at the beginning of the study term so that students can have an idea of how their learning will take place.

Neville (1999:400) states that students should be given a clear structural plan which is a course outline. Steinert (1996:203) believes that setting clear goals and objectives can be of assistance in student learning. It is imperative that students should be given some structure to guide them especially in their first year of study. Students who are already in the programme and has already experienced learning through facilitation process for example those in their second or third year of study, should be appointed as mentors to the novice to support them. Data collected also seem to indicate that facilitators were uncertain of their roles as some did not provide guidance to students. Facilitators should also be trained to equip them with facilitation skills.

\section{Recommendations}

Recommendations for the study are specifically focused on student orientation, empowerment and support as well as the role of facilitators.

\section{Orientation of learners}

Information about the learning method and facilitation process should be sent to the students when they apply to study so that they can make informed choices prior to acceptance. They should have knowledge of the method of learning they are going to use in their tertiary education. Knowledge of what one is dealing with helps alleviate anxieties and people can prepare themselves emotionally to deal with change.

The students should be given sufficient orientation to outline their work pattern throughout the year. In addition a structured plan should be provided especially with students who are in their first year of study since those who are completing are more experienced and have adapted to the process of facilitate

\section{Support for students}

- $\quad$ Student support is very important on this aspect to prevent frustrations amongst students especially, those that have never used facilitation process.

- $\quad$ Different methods of support can be implemented and these can include scaffolding and mentoring .

- Off-campus contact with facilitators on social basis can be organized to provide emotional support for the students.

\section{Empowering students}

- $\quad$ Activities such as team building exercise are important in order to get used to working in teams and rely on one another. This is important in PBL as students work in groups.

\section{The role of the facilitator}

- $\quad$ Further research is needed on the role and function of the facilitator in the nursing education environment as a lot of research has been done on facilitating and facilitators in business and online learning environment for example.

- The role of the facilitator should be clarified to the students.

\section{Summary}

The study was undertaken to assess the experiences of the nursing students of facilitation. Their problems and needs were identified and recommendations were made. The students found the change to self-directed learning difficult. Experiences led to the development of negative emotions in the students and they indicated that some facilitators lacked skills of the facilitation process. Recommendations were made and included that students should be thoroughly prepared for the facilitation process. The study indicates that facilitation is a challenging process for both students and facilitators.

\section{Bibliography}

BECKER, S 1999. Evaluation of problembased learning in an undergraduate nursing education programme. Bloemfontein: University of the Free State (M.Soc.Sc. in Nursing).

BOUD, D \& FELETTI, G 1991. Introduction. The challenge of problembased learning. London: Kogan Page.

BOULTON-LEWIS, GM; WILLS, L \& MUTCH, S 1996. Teachers as adult learners: Their knowledge of their own learning and implications for teaching. Higher Education. 32(1):89-106.

BRINK, HI 1996. Fundamentals of research methodology for health care professionals. Cape Town: Juta \& Co. Ltd.

BROCKBANK, A \& McGILL, I 1998. Facilitating reflective learning in higher education. Philadelphia: Open University Press. 
BROOKFIELD, S 1995. Adult learning: An overview. In: Tuinjman, A. (Ed.) International encylopedia of education. Oxford: Pergamen Press. http:// nl.edu.ace/resolyces/documents/ adultlearning.html.

BROWN, S \& SMITH, B 1996. Resource-b ased learning: Staff and educational development series. London: Kogan Page.

CHALMERS, D \& FULLER, R 1996. Teaching for learning at university: Theory and practice. London: Kogan Page.

CHARLIN, B; MANN, K \& HANSEN,P 1998. The many faces of problem-based learning: A framework for understanding and comparison. Medical Teacher. 20(4):323-329.

CHEN, SE; COWDROY, RM; KINGSLAND, AJ \& OSTWALD, MJ 1994. Reflections on problem-based learning. Sydney: Australian ProblemBased Learning Network.

CONRICK, M 1994. Problem-based learning - managing students transitions. In: Chen, S.E., Cowdroy, R.M., Kingsland, A.J. \& Ostwald, M.J. (Eds.) Reflections on problem-based learning. Sydney: Australian Problem-Based Learning Network.

CRESWELL, JW 1994. Research design. Qualitative and quantitative approaches. London: Sage Publication.

DAVIES, $P$ 2000. Approaches to evidence-based teaching. Medical Teacher. 22(1):14-21.

EATON, A 1999. Assessing learning needs. In: Hinchliff, S. (Ed.) The practitioner as teacher. $2^{\text {nd }}$ ed. Edinburg: Baillière Tindall

FIELD, PA \& MORSE, JM 1985. Nursing research. The application of qualitative approaches. London: Chapman \& Hall.

GELLING, L 1999. Ethical principles in health care research. Nursing Standard. 13(36):39-42.

GICZKOWSKI, W 1995. Are traditional general education requirements right for adults students? Adult Learning 6(2):13.
HALPERN, D.F. 1994. Changing college classrooms, new teaching and learning strategies for increasingly complex world. San Francisco: Jossey-Bass Publishers.

HOLTZHAUSEN, SW 1999. Change in higher education: The psychological experience of facilitators and coordinators in a resource-based learning course. Bloemfontein: University of the Free State (dissertation submitted in fulfilment of the requirements for Masters Societatis Scientiae).

KATZ, G 1995. Facilitation. In: Alavi, C. (Ed.) Problem-based learning in a health services curriculum 1995. London: Routledge.

LINCOLN, Y \& GUBA, E 1985. Naturalistic enquiry. California: sage.

LUNYK-CHILD, OI; CROOKS, D; ELLIS, PUJ; OFOSU, C; O"MARA, L \& RIDEOUT, E 2001. Self-directed learning: Faculty and student perceptions. Journal of Nursing Education, 40(3): 116-122.

MOLOTO, JC 1999. A model for the reintegration of marginalized adolescents into the community to facilitate the restoration, promotion and maintenance of their mental health. Johannesburg: Rand Afrikaans University (doctoral degree).

MULHOLLAND, H 1994. Teaching small groups: Facilitating learning. Hospital Update. 4(11):38-42.

NEVILLE, AJ 1999. The problem-based learning tutor: Teacher? Facilitator? Evaluator? Medical Teacher. 21(4):393401.

OMERY, A 1983. Phenomenology: A method for nursing research. Advances in Nursing Science. 5(2):49-63.

PARSE. RR; COYNE, AB \& SMITH, MJ 1985. Nursing research: Qualitative methods. Maryland: Brady Communications Co.

PEELO, M 1994. Helping students with study problems. London: The Society for Research into Higher Education and Open University Press.

POLIT, DE \& HUNGLER, BP 1993. Nursing research. Principles and methods. 5th ed. Philadelphia: J.B.
Lippincott Co.

REES, F 1991. How to lead work teams: Facilitation skills. Amsterdam: P. Feiffer \& Co

REPUBLIC OF SOUTH AFRICA, GOVERNMENT GAZETTE. 1997. education white paper 3: A programme for the transformation of higher education. Pretoria: Government Printer.

REPUBLIC OF SOUTH AFRICA. 1995. Ways of seeing the National Qualifications Framework. Pretoria: Human sciences research Council.

ROGERS, C 1998. Teacher expectations: Implications for school improvement. In: Shorrocks-Taylor, D. (Ed.) Directions in educational psychology. London: Whurr Publishers Ltd.

ROOTH, E 1995. Life skills: A resource book for facilitators. Menzini: MacMillan.

STEINERT, Y 1996. Twelve tips for effective small-group teaching in the health professions. Medical Teacher. 18(3):203-207

TAYLOR, 1 1997. Developing learning in professional education - partnership for practice. The Society for Research into Higher Education and Open University Press.

TOWNSEND, J 1994. Challenge models for learning and knowing. In: McMillan, M. \& Townsend, J. (Eds.) Reflections on contemporary. Augstralia: Butterworth/ Heinemann.

UYS, LR \& CASSIMJEE, R 1997. Implementating a problem-based curriculum in a university department. South African Journal of Higher Education. 11(1): 132-138.

WHITE, R \& EWAN, C 1991. Clinical teaching in nursing. London: Chapman \& Hall. 